\title{
The Effect of Learning Motivation and Social Support on Learning Achievement of the Students in Aisyiyah Female Orphanage Serangan Yogyakarta
}

\author{
Dyah Pikanthi Diwanti ${ }^{1{ }^{1 *}}$ Suryanto ${ }^{2}$ Sri Iswati ${ }^{3}$ Tri Siwi Agustina ${ }^{4}$ Hari Basuki
}

Notobroto $^{5}$

${ }^{1}$ Universitas Muhammadiyah Yogyakarta, Yogyakarta, Indonesia

Sekolah Pascasarjana Universitas Airlangga, Surabaya, Indonesia

${ }^{2}$ Universitas Airlangga, Surabaya, Indonesia

${ }^{3}$ Universitas Airlangga, Surabaya, Indonesia

${ }^{4}$ Universitas Airlangga, Surabaya, Indonesia

${ }^{5}$ Universitas Airlangga, Surabaya, Indonesia

*Email: dyah.pikanthi.diwanti-2019@pasca.unair.ac.id

\begin{abstract}
This research aims to find out whether there is a positive and significant effect of (1) learning motivation on students' achievement, (2) social support on students' achievement, (3) learning motivation, and social support on students' achievement. This research was quantitative, located at Aisyiyah female orphanage Serangan. The instrument used for data collection was the questionnaire method, and SPSS 17.0 was used as data calculation software. The questionnaire method was used to measure the effect of learning motivation and social support on the students' learning achievement, whereas SPSS 17.0 software was used to measure the students' learning achievement. The research result shows that Adj R Square value is 0,533, which means that learning achievement has been $53 \%$ affected by the variable of motivation and social support. The rest, $47 \%$, is explained by the external variable. It can be concluded that the independent variable (learning motivation and social support) has an effect on learning motivation.
\end{abstract}

Keywords: Orphanage, Motivation, Social Support, Achievement

\section{INTRODUCTION}

Education is the main component of improving life quality. Through education, an individual will be able to develop himself or herself and explore many things. Education does not only relate to skills and knowledge but also moral values. In society, there is a variety of social institutions as a sociological study. Islamic Boarding Schools and orphanages as educational institutions have a huge role in Indonesian social life.

The orphanage is a social welfare operational institution that is responsible for providing social welfare services to abandoned children by conducting social support and alleviation program, including parental substitute services for fulfilling physical, mental, and social needs so that the children may have better, more accurate, and more appropriate chance to develop themselves as the future generations of the nation, as well as an individual who will actively contribute to the national development. The existence of orphanage as one of the social institutions that have specific social department implementation standards should play an important role in society. Muhammadiyah is known as amar ma'ruf nahi munkar (enjoining what is right and forbidding what is reprehensible) missionary endeavor. This statement represents Muhammadiyah's commitment as described in Surah Ali Imran: 104, a surah that becomes the main factor underlying the establishment of Muhammadiyah.

Muhammadiyah has been progressing in Indonesia by establishing several charity programs that have helped many people, including educational, social, and health institutions.

Learning motivation is one's internal and external encouragement to gain behavioral changes in the middle 
of the learning process, generally under particular supporting indicators or elements [1]. Motivation represents one's self-encouragement to perform something in accordance with his or her intention. High motivation in learning enables an individual to achieve high learning outcomes. It means that the higher the motivation is, the higher the effort intensity will be performed. Therefore, an individual's action could be based on a specific encouragement that aligns with the underlying thematic motivation.

Another factor that could improve a student learning achievement is social support, or generally known as the learning environment, by which learning environment involves the environment of family, school, and society. Social environment as social support is anything outside an individual where he or she is associating with other people either at the surrounding community or outside school

Panti Asihan Yatim (PAY) Putri Aisyiyah Serangan is one of the orphanages which has been accredited under the Muhammadiyah organization. PAY has an institutional curriculum in the form of semi Islamic Boarding School as madrasah diniyah (an institution that focuses on teaching religious education). This program is an addition to the students' formal educational program acquired at the former public school. This semi Islamic Boarding School study program includes religious material exploration, general education, and Al-Qur'an and hadith memorization. There are 54 students in PAY PutriSerangan, including 106 students outside of the orphanage, with a total number of 90 elderly people. This phenomenon emphasizes that the existence of orphanage is influential for society.

Motivation is the encouragement that is able to change an individual's behavior and is able to trigger his or her enthusiasm to be a better individual [2]. Panti Asuhan Putri Muhammadiyah Probolinggo has always motivated the students so that they have selfencouragement and spirit in performing anything since motivation determines the students' achievement. In addition, social support either from the family, fellow classmates, or surrounding orphanage environment, has contributed to the students' development in learning achievement.

\section{METHODOLOGY}

The research method used was the quantitative method. This was intended to test the hypothesis. Likert Scale was used in this research.

1. Population and Sample

\section{a. Population}

The population in this research was students in Panti Asuhan Yatim Putri Aisyiyah Serangan Yogyakarta.

b. Sample

The sampling in this research used Roscue theory, where the number of a sample that can be taken is $40-500$ respondents. In this research, 40 respondents were chosen as the sample.

\section{Data Collection Technique}

a. Questionnaire

The method used in this research was the Likert-Scale questionnaire.

\section{b. Documentation}

This method is used to complete data which deal with a general description of the studied institution/object.

\section{Variable Operational Definition}

Variable is anything stipulated by a researcher to study, in which information could be generated from, then drawn into conclusion [3]. There are two independent variables and one dependent variable in this research. Based on the definitions, there are two variables in this research:

a. Independent variable (X), which is learning motivation and social support behavior

b. Dependent variable (Y), which is learning achievement

4. Instrument Test

a. Validity Test

Validity is the level of measurement to measure what is supposed to be measured. The analysis tool used to measure the data validity level was the correlational coefficient through SPSS 17.0 Software.

b. Reliability Test

The reliability of each variable was tested using Cronbach Alpha Coeficient via SPSS 17.0 Software. In addition to the validity and reliability test, the T-test, ANOVA test, and others were also conducted.

5. Classical Assumption Test

a. Multicollinearity Test

The detection towards multicollinearity is by analyzing the dependent variables correlational matrix or by investigating the tolerance and variance inflation factor (VIF) 
value. If the VIF and tolerance value is equal to or more than 0.1 , it can be considered multicollinearity free [4].

b. Normality Test

A good regression model should have a normal or approximately normal distribution.

c. Heteroscedasticity Test

Gletser test is used to detect the heteroscedasticity by investigating the significance level of the residual absolute value regression result as the dependent variable with its characteristic variable. Heteroscedasticity detection could either be performed by investigating specific heaving, widening, or shrinking patterns in the Scatterplot graphic between the standardized predicted values (ZPRED) and the standardized residual (SRESID).

6. Data Analysis Method

Descriptive statistics is the statistics used to analyze data by describing the collected data as naturally without any intention to draw a generalized conclusion [7].

\section{a. Prerequisite Analysis Test}

There was a prerequisite analysis test so that the drawn conclusion did not deviate from the truth. Therefore, linearity and hypothesis tests were required to fulfill the prerequisite.

b. Linearity Test

The linearity test is intended to determine whether each of the predictor independent variables has an either linear or random correlation with the dependent variables.

\section{Hypothesis Test}

The hypothesis test in this research was through bivariate analysis. Bivariate analysis is used to test the first and second hypotheses.

a. Partial Significance Test (T-Test)

According to (Sugiyono, 2012), a t-test is used to determine the effect of an individual variable [7].

b. Simultaneous Test (F)

The f-test explains whether all independent variables included in the model have a simultaneous effect on the dependent variables [7].

c. R Determination Test

If the R2 value is low, it can be considered that the capability of independent variables in explaining dependent variables is minimal. In contrast, if the value is approximate to one, the independent variables are capable of providing the required information to predict the dependent variables.

\section{RESULT AND DISCUSSION}

\subsection{Validity Test}

A valid statement can be defined as the instrument that can be used as a measurement of what aspect will be measured in the research [5]. Validity measurement is taken by comparing the value of rcountwith rtable. The sample in this study was 79 people. As a result, the rtable having a significance level of 0.05 with a total number of data, 79 , is 0.221 . If the rcount is greater than the rtable and is positive, the statement or indicator is considered valid.

After the analysis was conducted, the results shown suggest that all of the question items were valid. It is seen from the value of rcount, which was greater than the rtable and the significance value was less than 0.05 in all statements of the instrument. Hence, all statements can be used as the research instrument measuring tools.

\subsection{Reliability Test}

If the measurements used do not change when the observation is carried out and the results obtained are accurate and stable, it can be declared as reliable [5]. The followings are the results of the reliability test:

This study shows that all statements have a Cronbach's Alpha>rtable value. Therefore, it can be concluded that each variable used in this study is reliable. As a result, if the instrument in this study is used several times to measure the same object, it will result in the same data [5].

\subsection{Classic Assumption Test}

In accordance with the thinking framework, the classic assumption test, including the multicollinearity test, heteroscedasticity test, and normality test, is continued with multiple linear regression tests, namely the R2 test, F test, and T-test.

\subsubsection{Multicollinearity Test}

The data that is free from multicollinearity problems have the VIF value, which is less than ten, and the Tolerance value, which is more than 0.10 . 
Table 1. Multicollinearity Test Results

\begin{tabular}{|l|c|c|}
\hline \multicolumn{1}{|c|}{ Variable } & Tolerance & VIF \\
\hline Motivation & 0,528 & 1,895 \\
\hline Social Support & 0,528 & 1,895 \\
\hline
\end{tabular}

Source: Data Processing Results, 2020

From Table 1, it can be seen that the VIF value is below 10. The value for motivation is 1.895 , and social support is 1.895. In addition, the Tolerance value is more than 0.10 , which is motivation 0.50 and social support is 0.528 . Therefore, it can be concluded that there is no multicollinearity in this study, so this research is worth to be taken.

\subsubsection{Heteroscedasticity Test}

This study applied Glejser Test. Glejser test is a test checking the hypotheses by regressing absolute residuals. It is defined that there is no heteroscedasticity problem if the significance value of the independent variable is more than 0.05 , meaning that the independent variable does not affect the dependent variable.

Table 2. Heteroscedasticity Test Results

\begin{tabular}{|l|c|}
\hline Variable & Significance \\
\hline Motivation & 0,061 \\
\hline Social Support & 0,657 \\
\hline
\end{tabular}

Source: Data Processing Results, 2020

Table 2 shows that the significance value for motivation is 0,061 and social support is 0.657 . From these results, it has a value of more than 0.05 , which means there is no heteroscedasticity. It shows that there is heteroscedasticity in the regression model. Hence, the regression model is appropriate to be used in predicting the variables tested.

\subsubsection{Normality Test}

The normality test is used to reveal if the independent variable or the dependent variable has a normal distribution in the regression model. This test applies a statistical analysis that is through One-Sample Kolmogorov-Smirnov Test. The normality test considers the results of the Asymp sig. with $\alpha=0.05$. The criterion in the testing is if the value in Asymp sig. $\geqslant a=0.05$, the data are normally distributed. The followings are the results of the One-Sample Kolmogorov-Smirnov Test:

Table 3. Normality Test Results

\begin{tabular}{|l|c|}
\hline & Unstandardized Residual \\
\hline Asymp.sig.(2-Tailed) & .463 \\
\hline
\end{tabular}

Source: Data Processing Results, 2020
From Table 3, it can be seen that the Asymp value. Sig. (2-tailed) is 0.463 , meaning that it has a value of $\geqslant$ 0.05 . As a result, the data are normally distributed.

\subsection{Multiple Regression Analysis}

\subsubsection{Determination Coefficient Test $\left(R^{2}\right)$}

The followings are the results of the coefficient of determination test:

Table 4. Determination Coefficient Test Results

\begin{tabular}{|c|c|c|c|}
\hline $\mathrm{R}$ & $\mathrm{R}$ Square & $\begin{array}{c}\text { Adjusted R } \\
\text { Square }\end{array}$ & $\begin{array}{c}\text { Standard Error } \\
\text { of Estimate }\end{array}$ \\
\hline $0,746^{\mathrm{a}}$ & 0,557 & 0,533 & 3,170 \\
\hline
\end{tabular}

Source: Data Processing Results, 2020

Table 4 shows that the value of Adj R Square is 0.533, which means that learning achievement is influenced as many as $53 \%$ by the variable of motivation and social support. Motivation is the encouragement that is able to change an individual's behavior and is able to trigger his or her enthusiasm to be a better individual and also about social support [2]. Therefore, the remaining $47 \%$ is explained by other variables other than the model in this study. It can be concluded that the independent variables affect learning achievement.

\subsubsection{Simultaneous Significance Test (Statistical F Test)}

This test is intended to reveal if all independent variables in the model have a simultaneous influence on the dependent variable. It is taken by comparing Fcount to Ftable at a significance level of 5\%. It means that if Fcount is greater from Ftable and Sig. Value is smaller than 0.05 , there is a significant influence between the independent variable and the dependent variable simultaneously. The results of the simultaneous significance test are below:

Table 5. Simultaneous Significance Test Results

\begin{tabular}{|l|c|c|c|c|c|}
\hline \multicolumn{1}{|c|}{ Model } & $\begin{array}{c}\text { Sum of } \\
\text { Squares }\end{array}$ & df & $\begin{array}{c}\text { Mean } \\
\text { Square }\end{array}$ & F & Sig. \\
\hline $\begin{array}{l}\text { Regressi } \\
\text { on }\end{array}$ & 466,671 & 2 & 233,335 & $\begin{array}{c}23,3 \\
35\end{array}$ & $\begin{array}{c}, 000 \\
\text { b }\end{array}$ \\
\hline Residual & 371,729 & 3 & 10,047 & & \\
\hline Total & 838,400 & $\begin{array}{c}3 \\
9\end{array}$ & & & \\
\hline
\end{tabular}

Source: Data Processing Results, 2020

Based on Table 8 above, it can be seen that the value of significance is 0,000, and Fcount value is 23,225. With a significance level of five percent and df $1=(\mathrm{k}-1)$ $=3-1=2(\mathrm{k}$ is the parameter in the model $)$ and $\mathrm{df} 2=$ (nk) $=40-3=37$ ( $\mathrm{n}$ is the amount of research data and $\mathrm{k}$ is the number of parameters in the model), the score of 
Ftablewhich is 3.25 is obtained. The value of Fcount, which is 23,225 , is greater than the value of Ftable, which is 3.25 , and the value of Sig. of 0,000 is smaller than 0.05 . These results indicate that the variable of motivation and social support simultaneously have a positive and significant influence on learning achievement.

\subsubsection{Individual Parameter Significance Test (Statistical T-Test)}

The test can be done by comparing the tcount to the ttable. A hypothesis is accepted if the value of tcount is greater than the ttable or the significant value is less than 0.05 . Below are the results of the $t$ statistical test:

Table 6. Individual Parameter Significance Test Results

\begin{tabular}{|l|c|c|}
\hline \multicolumn{1}{|c|}{ Variable } & $\mathrm{t}$ & Sig. \\
\hline Motivation & 2,940 & 0,006 \\
\hline Social Support & 2,446 & 0,019 \\
\hline
\end{tabular}

Source: Data Processing Results, 2020

Based on the results of the partial significance test in Table 6 the following information is found:

\subsection{The Test of Hypothesis}

\subsubsection{The Test of Hypothesis One (H1)}

In accordance with Table 6 , it is found that the value of the variable of motivation is 0.006 . These results indicate that the significance value is less than 0.05 , and the value of tcount is 2.940 , which is greater than the ttable, which is 2.026. Thus, it can be concluded that $\mathrm{H} 1$ is accepted. It suggests that motivation has a positive and significant influence on learning achievement.

\subsubsection{The Test of Hypothesis Two (H2)}

Based on Table 6, it can be seen that the value of social support is 0.019 . These results indicate that the significance value is less than 0.05 , and the tcount value of 2.446 is greater than the table that is 2.026. Thus, it can be concluded that $\mathrm{H} 2$ is accepted that is social support has a positive and significant influence on learning achievement.

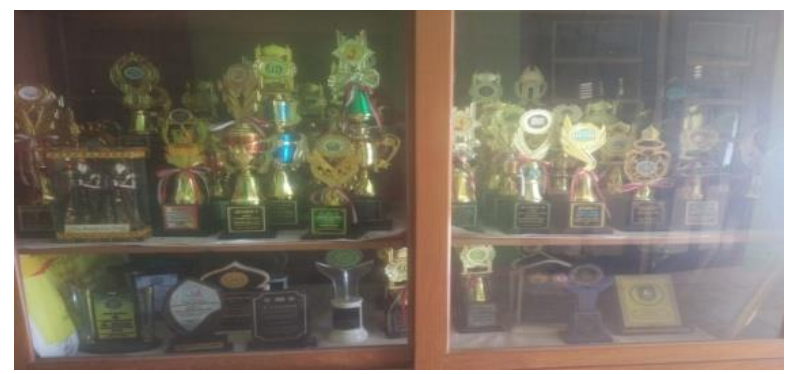

Picture 1. Aisyiyah Female Orphanage Serangan Yogyakarta
According to Sardiman, there are various types of motivation, namely intrinsic motivation and extrinsic motivation.

Based on the data summarized in this study, they support that the existence of the orphanage illustrates similar situations making it a semi-boarding school include [6].

1. The existence of the students who are the orphans living and participating in learning activities that are supported by a number of achievements of orphans who participate in competitions (as documented in the photo above).

2. The existence of the boarding that is the facility provided by the orphanage supporting the learning process such as teaching-learning rooms, computer room, and the orphanage's official car, and a hall for meetings.

3. The existence of the musholla (Islamic prayer room) as a religious activity done with the caregivers and educators.

4. There is a structure of caregivers and administrators.

5. The existence of a curriculum that is under the Guidance and Education Unit in Panti Asuhan Yatim Putri Aisyiyah, namely formal education conducted in their schools respectively and informal education organized by the orphanage through Diniyah school (an integrated of national education to fulfil the religious learning demands) which is a semiboarding school having religious, general, and memorizing learning materials. As well as nonformal education, there is also vocational training centers (BLK-PAY) that facilitate the orphanage children in joining training and other supporting programs [7]. The learning in Panti Asuhan Yatim Putri Aisyiyah has been managed to develop intellectual and spiritual intelligence for children with different parenting backgrounds and emotional intelligence of each child in the orphanage in responding to themselves and the conditions in the orphanage in the care of the orphanage administrators. In addition, learning is done by providing wide insight so that it is able to accept all aspects and scope in terms of learning content, learning methods, learning process, subject of educators/caregivers, and evaluation well. It is illustrated from 1) doing tahajud (midnight) prayer and subuh (morning) prayer every day together; 2 ) cooperating to clean the orphanage environment; 3 ) uttering prayer together; 4) doing Magrib and Isya' prayer and Islamic studies; 5) always celebrating religious holidays, for example, Eid al-Adha; 6) making study groups; 7) reciting Qur'an or qataman (finishing the Qur'an recitation until the last verse); 8) learning to join the organization. 


\section{CONCLUSION}

Based on the results obtained from data processing, it can be concluded that:

1. After the analysis has been taken, the results shown indicate that all statement items are valid. This can be seen from the rcount value, which is greater than rtable, and the significance value, which is less than 0.05 on all statements of the instrument. In this study, it shows that all statements have a Cronbach's Alpha> rtable value. Hence, it can be concluded that each variable used in this study is reliable.

2. From Table 1, it can be seen that the value of VIF is below 10. The value for motivation is 1.895 , while social support is 1.895. Meanwhile, the Tolerance value is greater than 0.10 , which is 0.528 for motivation and 0.528 for social support. Therefore, it can be concluded that there is no multicollinearity in this study, so it is worthy of research. From Table 2, it shows that the significance value of motivation is 0,061 and social support is 0,657 . From these results, it has a value that is more than 0.05 , meaning that there is no heteroscedasticity. Table 3 shows that the Asymp value. Sig. (2-tailed) of 0.463 , which means it has a value of $\geqslant 0.05$. Hence, the data are normally distributed.

3. Table 4 shows that the value of Adj R Square is 0.533 , meaning that learning achievement is influenced as many as $53 \%$ by the variable of motivation and social support. According to Widia (2012:8), motivation is the encouragement that is able to change an individual's behavior and is able to trigger his or her enthusiasm to be a better individual and also about social support.

4. The remaining $47 \%$ is explained by other variables other than the model in this study. Thus, it can be concluded that the independent variables affect learning achievement.

5. Based on Table 5 above, it can be seen that the value of significance is 0,000, and Fcount value is 23,225. With the significance level of five percent and df1 = $(\mathrm{k}-1)=3-1=2(\mathrm{k}$ is the parameter in the model $)$ and $\mathrm{df} 2=(\mathrm{nk})=40-3=37$ ( $\mathrm{n}$ is the amount of research data and $\mathrm{k}$ is the number of parameters in the model), the value of Ftablewhich is 3.25 is obtained. The value of Fcountwhich is 23,225 is greater than the value of Ftablewhich is 3.25 , and the value of Sig. Which is 0,000 is smaller than 0.05 . These results indicate that the variable of motivation and social support have a simultaneous positive and significant influence on learning achievement.

6. Based on Table 6, it is revealed that the value of the variable of motivation is 0.006 . These results indicate the significant value, which is less than 0.05 , and the value of tcount, which is 2.940 , is greater than the ttable, which is 2.026 . Therefore, it can be concluded that $\mathrm{H} 1$ is accepted. Motivation has a positive and significant influence on learning achievement.

7. Based on Table 6, it can be found that the value of social support is 0.019 . This result indicates that the significance value is less than 0.05 , and the value of tcount, which is 2.446 , is greater than the ttable, which is 2.026. Thus, it can be concluded that $\mathrm{H} 2$ is accepted that is social support has a positive and significant effect on learning achievement.

\section{REFERENCES}

[1] Uno, Hamzah. 2012. Teori Motivasi dan Pengukurannya. Jakarta: PT Bumi Aksara.

[2] Widya, Narulita. 2012. Penggunaan Metode College Ball Dalam Upaya Meningkatkan Motivasi Belajar IPS Kelas VIII B SMP N 1 Reban Batang. Yogyakarta: Universitas Negeri Yogyakarta.

[3] Sugiyono. (2012). Memahami Penelitian Kualitatif. Bandung: ALFABETA.

[4] Ghozali, I. (2001). Aplikasi Analisis Multivariate Dengan Program. Semarang: Badan Penerbit Universitas Diponegoro.

[5] Sugiyono. (2010). Statistika Penelitian. Bandung: CV. Alfabeta.

[6] Idi, Abdullah dan Safarina. 2011. Sosiologi Pendidikan Individu, Masyarakat, dan Pendidikan. Jakarta: PT Raja Grafindo Persada

[7] Winda Anggunita Lestari (2016). Peran Lembaga Kesejahteraan Anak dalam Menanamkan Pendidikan Karakter Terhadap Anak Asuh Di Panti Asuhan, Jurnal Civic Hukum, UMM 